\title{
ПРОБЛЕМЫ ВЫПЛАТЫ ВОЗНАГРАЖДЕНИЯ АВТОРАМ И ПРАВООБЛАДАТЕЛЯМ В СЛУЧАЯХ, ПРЕДУСМОТРЕННЫХ ЗАКОНОМ
}

\author{
(c) 2018 Данилов Юрий Сергеевич \\ Генеральный директор ООО «ЮСД Групп» \\ 129110, г. Москва, пр-кт. Олимпийский, д. 16, стр. 5
}

Статья посвящена рассмотрению проблем, связанных с выплатой авторам и иным правообладателям специального вознаграждения, установленного действующими для отдельных случаев законодательными положениями, предусмотренными частью четвертой ГК РФ.

В статье обосновывается вывод о том, что для реализации права на вознаграждение, установленного законом, необходима разработка специального порядка защиты прав, основанного на общих положениях гражданского законодательства. Автором также отмечается нецелесообразность распространения принципов, лежащих в основе компенсационных подходов, при определении размера возмещения убытков, подлежащего взысканию с нарушителей права на вознаграждение.

Ключевые слова: произведение, служебное произведение, автор, авторское право, правообладатель, исключительное право, вознаграждение, защита авторских прав, смежные права, интеллектуальная собственность, интеллектуальные права, убытки, возмещение убытков.

Технологическое развитие привело к появлению новых и модернизации ранее существовавших способов использования произведений, исполнений, фонограмм, передач вещательных организаций и баз данных. Новые технические возможности способствуют расширению использования объектов авторского права и смежных прав в образовательной, культурной, научной и иных социально важных сферах. Развитие электронных образовательных технологий, новых средств и способов предоставления доступа к произведениям для лиц с физическими проблемами, в частности, для слепых и слабовидящих [2], предоставление удаленного доступа к библиотечным, музейным и архивным фондам, реализация культурных, информационных, образовательныхи иных проектов приводит к необходимости выработки новых решений, позволяющих обеспечить соблюдение прав авторов и иных правообладателей в новых условиях.

На протяжении длительного времени решения, необходимые для соблюдения баланса интересов правообладателей и общества и достижения образовательных, культурных или иных социально важных целей, сводились, как правило, к установлению специальных ограничений исключительных прав на произведения и объекты смежных прав. Однако установление новых ограничений в отношении складывающихся современных способов использования произведений может привести к причинению существенного ущерба правообладателям.
Так, по данным Федерального агентства по печати и массовым коммуникациям доля изданий, выходящих тиражом менее 500 экз., в 2017 году достигла 50\% от общего числа выпускаемых наименований [5]. При этом общее число выпускаемых экземпляров книг снизилось за последние 10 лет почти в 1,75 раза: с 5,35 в 2008 г. до 3,2 в 2017 г. [5] В таких условиях любое дополнительное ограничение прав издателей и авторов издаваемых произведений способно самым существенным образом повлиять на ситуацию на книжном рынке. Аналогичным образом ситуация обстоит во многих других отраслях, связанных с созданием и использованием результатов интеллектуальной деятельности.

В соответствии с пунктом 5 статьи 1229 Гражданского кодекса Российской Федерации (далее - ГК РФ) установление ограничений исключительных прав допускается только при условии, что такие ограничения не нанесут «неоправданный ущерб» обычному использованию произведений или иных объектов интеллектуальных прав и что законные интересы правообладателей не будут ущемлены «необоснованным образом».

Данные положения следуют из так называемого «трех шагового теста», предусматриваемого в отношении допускаемых ограничений права на воспроизведение в соответствии с пунктом 2 статьи 9 Бернской конвенцией об охране литературных и художественных произведений, согласно которому устанавливается также до- 
полнительное требование о том, что ограничения допустимо устанавливать только для «определенных случаев» [6].

Анализ судебной практики показывает, что ограничения исключительных прав нередко используются для ухода нарушителей от ответственности, в том числе за счет чрезмерно широкого толкования законодательных положений, закрепляющих такие ограничения.

В качестве примера может быть приведено дело, включенное в пункт 11 Обзора судебной практики по делам, связанным с разрешением споров о защите интеллектуальных прав, утвержденного Президиумом Верховного Суда Российской Федерации 23 сентября 2015 г. Суды нескольких инстанций отказались удовлетворить законные требования автора, обратившегося за защитой своих прав в связи с частичным использованием его произведения при издании курса лекций. Суды обосновывали свою позицию тем, что «частичное использование ответчиком опубликованного произведения в печатном виде курса лекций в незначительном количестве экземпляров имело место в его профессиональной деятельности - преподавательской, а именно для чтения лекций, то есть в целях удовлетворения собственных профессиональных потребностей, что является воспроизведением в личных целях» [4].

Определением Судебной коллегии по гражданским делам Верховного Суда Российской Федерации от 24 мая 2011 г. № 5-В11-32 указанные доводы были признаны ошибочными, поскольку положения статьи 1273 ГК РФ о свободном воспроизведении произведений представляют собой исключение из общего правила об использовании произведений только с согласия правообладателей и допускают воспроизведение произведений без согласия их авторов и иных правообладателей только при доказанности того, что такое воспроизведение осуществляется в личных целях.

Законодательством не предусмотрена, в частности, возможность свободного воспроизведения произведений для удовлетворения профессиональных потребностей: «Использование ответчиком напечатанной (воспроизведенной) книги в процессе повседневной трудовой преподавательской деятельности для чтения лекций нельзя считать личным использованием, поскольку в данном случае она используется не для собственных (семейных, бытовых) по- требностей и не для решения своих личных дел в процессе работы, а для потребностей обучающихся» [4].

Судебная коллегия при рассмотрении данного дела также отметила, что преподавательская деятельность в форме чтения лекций сопровождается получением ответчиком вознаграждения (оплаты труда) и не может рассматриваться в качестве благотворительной некоммерческой деятельности даже при отсутствии факта выплаты вознаграждения за изданное произведение.

Вместе с тем, можно представить те сложности, с которыми столкнулся бы автор малотиражного издания при попытке заключения договоров в отношении фрагментов произведений, необходимых ему для использования при составлении хрестоматии или формировании материалов курса, а также еще большие сложности, связанные с формированием электронных библиотечных систем и иных аналогичных электронных ресурсов, включающих произведения и объекты смежных прав множества правообладателей. Выходом из сложившейся ситуации может стать постепенная замена ограничений, допускающих свободное использование произведений и объектов смежных прав, на ограничения, предусматривающие возможность использования произведений и объектов смежных прав в определенных случаях без согласия правообладателей, но с выплатой им вознаграждения. Исключительное право для таких случаев не ограничивается полностью, а сводится только к праву на получение вознаграждения.

Подход, основанный на признании права на «компенсационное вознаграждение», «дополнительное вознаграждение», «справедливое вознаграждение» при установлении ограничений исключительных прав авторов и иных правообладателей является характерной тенденцией развития законодательства Европейского Союза.

В соответствии с Директивой ЕС от 22.05.2001 года № 2001/29/ЕС «О гармонизации некоторых аспектов авторского права и смежных прав в информационном обществе» [1] выплата вознаграждения предусматривается для большинства случаев установления ограничений, в которых ранее признавалось допустимым осуществлять свободное использование произведений без согласия правообладателей и без выплаты им какой-либо компенсации за такое использование.

Так, например, подпункт «а» пункта 2 статьи 5 Директивы предусматривает, что исключе- 
ние в отношении воспроизведения произведений «на бумаге или любом подобном носителе», осуществляемого путем фотокопирования, ксерокопирования и иным подобным образом, действует только при условии, что правообладатели получают обоснованную компенсацию. ГК РФ в настоящее время не предусматривает выплаты компенсации за указанное воспроизведение произведений, допуская его свободное осуществление в широком перечне случаев образовательными, библиотечными и архивными учреждениями (статья 1275 ГК РФ).

Подпункт «b» пункта 2 статьи 5 Директивы устанавливает ограничение «относительно воспроизведений на любом носителе ... физическим лицом в частных целях, которые ни непосредственно, ни косвенно не являются коммерческими при условии, что правообладатели получают обоснованную компенсацию». В отличие от данных положения нормы статьи 1245 ГК РФ устанавливают выплату компенсационного вознаграждения только за частное копирование фонограмм и аудиовизуальных произведений. Выплата вознаграждения за копирование в личных целях литературных, изобразительных и иных произведений законодательством Российской Федерации не предусмотрена.

Аналогичным образом подпунктом «е» пункта 2 статьи 5 Директивы предусматривается ограничение исключительных прав в отношении действий, осуществляемых «социальными учреждениями, преследующими некоммерческие цели, такими как больницы или тюрьмы, при условии, что правообладатели получают обоснованное вознаграждение». Подпунктом 6 пункта 1 статьи 1274 ГК РФ для подобных случаев устанавливается возможность использования произведений без выплаты какого-либо вознаграждения правообладателям.

Подпункт «а» пункта 3 статьи 5 Директивы предусматривает необходимость выплаты вознаграждения правообладателями даже в случае установления ограничений в отношении использования произведений «для единственной цели иллюстрации для обучения или научного исследования», что также отличается от подхода, закрепляемого ГК РФ (подпункт 2 пункта 1 статьи 1274 ГК РФ) и предусматривающего возможность свободного использования произведений в качестве иллюстраций в изданиях, радио- и телепередачах, звуко- и видеозаписях учебного характера.
Выплата специально установленного законом вознаграждения предусмотрена статьей 1245, пунктом 3 статьи 1263, статьей 1293, пунктом 2 статьи 1295, статьей 1326 ГК РФ. Реализация положений данных статей сталкивается на практике с рядом сложностей, обусловленных как недостатками нормативно-правового регулирования, так и организационными проблемами.

Неясной является, в частности, природа права на вознаграждение в тех случаях, когда такое вознаграждение устанавливается законом в качестве ограничения исключительного права (статьи 1245, 1263, 1326 ГК РФ) и в качестве отдельной специальной выплаты, как это имеет место в отношении права следования (статья 1293 ГК РФ).

В пункте 10.1 совместного Постановления Пленума Верховного Суда Российской Федерации, Пленума Высшего Арбитражного Суда Российской Федерации от 26 марта 2009 г. № 5/29 «О некоторых вопросах, возникших в связи с введением в действие части четвертой Гражданского кодекса Российской Федерации» отмечается, что «по смыслу положения пункта 5 статьи 1229 ГК РФ право на вознаграждение входит в состав исключительного права». При этом в пункте 10.2 указывается на то, что право на вознаграждение сохраняется у автора и иного первоначального обладателя такого права даже в тех случаях, когда исключительное право не принадлежит такому лицу.

Данный подход привел к тому, что на практике договорные условия о полной передаче (отчуждении) исключительного права на произведение или объект смежных прав стали признаваться недостаточными для признания перехода права на получение вознаграждения, установленного, в частности, вышеуказанными статьями 1245, 1263, 1326 ГК РФ.

В пункте 10.5 рассматриваемого Постановления отмечается иной подход, согласно которому право следования (статья 1293 ГК РФ) является самостоятельным правом автора, отличным от принадлежащего ему исключительного права на произведение. При этом законодатель существенным образом ограничивает возможность распоряжения данным правом, допуская его переход только к наследникам автора.

Наконец, в отношении права на вознаграждение за служебное произведение пунктом 2 статьи 1295 ГК РФ предусматривается его полная 
неотчуждаемость и отсутствие перехода даже по наследству, при этом признается возможность перехода по наследству прав автора по договору, заключенному им с работодателем.

Такое разнообразие подходов и толкований усугубляется тем, что действующее законодательство не содержит специальных положений, определяющих порядок защиты прав на предусматриваемое законом вознаграждение, связанное с созданием или использованием произведений или объектов смежных прав.

В соответствии с пунктом 1 статьи 1250 ГК РФ интеллектуальные права могут защищаться способами, предусмотренными ГК РФ, с учетом существа нарушенного права и последствий его нарушения. Таким образом, при невыплате установленного законом вознаграждения автор и иной получатель вознаграждения вправе требовать возмещения убытков согласно положениям статьи 12 ГК РФ.

Однако в пункте 5, устанавливающем меры, которые могут быть приняты в отношении нарушителя при отсутствии его вины, взыскание причитающегося вознаграждения или возмещение убытков не указаны, что создает основания для отказа в выплате вознаграждения правообладателям в случаях, когда невыплата вознаграждения обусловлена причинами, не зависящими от лица, обязанного осуществлять такие выплаты, при условии что такое лицо не является коммерческим юридическим лицом или индивидуальным предпринимателем.

В статье 1252 ГК РФ вопрос о последствиях нарушения права на вознаграждение, установленное законом, отдельно не выделяется. Подпунктом 1 пункта 1 указанной статьи предусматривается, что защита исключительных прав может осуществляться путем предъявления требования о возмещении убытков при бездоговорном использовании произведений, сопряженном с нарушением исключительных прав на такие произведения и причинившем ущерб правообладателю, «в том числе нарушившему его право на вознаграждение, предусмотренное статьей 1245, пунктом 3 статьи 1263 и статьей 1326 Кодекса».

Приведенные положения содержат существенные противоречия, так как в указанных случаях ущерб может быть причинен не нарушением исключительного права, а именно невыплатой вознаграждения, установленного законом, причем ущерб может быть причинен не только правообладателю, но и другим законным получателям такого вознаграждения, в том числе не являющимся правообладателями - обладателями исключительных прав.

Существенные проблемы, с которыми на практике сталкиваются авторы, правообладатели, организации, управляющие имущественными авторскими и смежными правами на коллективной основе, при попытках истребования предусмотренного законодательством вознаграждения, приводят к предложениям распространить на случаи невыплаты такого вознаграждения возможность взыскания компенсации за нарушения исключительных прав: «Взыскиваемая в указанных случаях штрафная компенсация может выступать в качестве законной неустойки, стимулирующей пользователей (плательщиков) к выполнению законодательных и договорных требований и позволяющей эффективно защищать права и охраняемые законом интересы создателей результатов творческой деятельности» [3].

Однако такое предложение представляется недостаточно обоснованным, так как речь идет о взыскании конкретного, предусмотренного законом вознаграждения, размер которого должен определяться в установленном законом порядке, между сторонами отсутствуют договорные отношения, а сама по себе невыплата приводит к причинению автору или иному правообладателю убытков в объеме неполученного им вознаграждения, не влияя при этом на условия использования произведений или объектов смежных прав и на доходы, получаемые от такого использования.

Как представляется, в случае невыплаты вознаграждения, предусмотренного статьей 1245 , пунктом 3 статьи 1263, статьей 1293, пунктом 2 статьи 1295 или статьей 1326 ГК РФ, размер взыскиваемых сумм должен определяться на основании объективных показателей. Задержка выплаты вознаграждения при этом может компенсироваться за счет взыскания специальной неустойки (пени), которая может быть предусмотрена законодательством по аналогии с установленной статьей 395 ГК РФ возможностью истребования процентов на сумму долга в случае неправомерного удержания денежных средств.

Размер предусматриваемой законодательством для указанных случаев неустойки должен быть достаточным для того, чтобы стимулиро- 
вать плательщика к исполнению предусмотренных законодательством обязанностей, поэтому целесообразно увеличивать размер взыскиваемой неустойки (пени) с установлением прогрессивной шкалы в зависимости от срока невыплаты предусмотренного законом вознаграждения, причитающегося авторам и иным правообладателям. Подобный подход нашел применение, в частности, в статье 155 Жилищного кодекса Российской Федерации при определении размера пени, начисляемой при невнесении платы за жилое помещение или коммунальные услуги, возрастающего в зависимости от срока допу- щенной просрочки.

Предлагаемые меры позволят обеспечить эффективную реализацию положений о выплате вознаграждения, установленного законом, и тем самым создадут предпосылки для расширения допускаемого перечня ограничений исключительных прав на произведения и объекты смежных прав в необходимых случаях с одновременным установлением дополнительного компенсационного вознаграждения, подлежащего выплате авторам и иным правообладателям.

\section{Библиографический список}

1. Директива ЕС № 2001/29/ЕС от 22 мая 2001 г. о гармонизации некоторых аспектов авторского права и смежных прав в информационном обществе // Законодательство Европейского Союза об авторском праве и смежных правах. Сборник директив Европейского парламента и Совета в области авторского права и смежных прав / Под ред. В.В. Орловой.- Пер. Л.И. Подшибихин, В.Г. Оплачко.- М.: ФИПС, 2002

2. Марракешский договор об облегчении доступа слепых и лиц с нарушениями зрения или иными ограниченными способностями воспринимать печатную информацию к опубликованным произведениям от 27 июня 2013 г. // Публикация на официальном сайте Всемирной организации интеллектуальной собственности. URL: http://www.wipo.int

3. Музыка Ф.А. Компенсация как способ защиты исключительных прав на произведения и объекты смежных прав. Диссертация на соискание ученой степени кандидата юридических наук. Москва. 2011. 211 с.

4. Обзор судебной практики по делам, связанным с разрешением споров о защите интеллектуальных прав, утвержденного Президиумом Верховного Суда Российской Федерации 23 сентября 2015 г. // Справочно-правовая система «Консультант Плюс».

5. Отраслевой доклад. Книжный рынок России. Состояние, тенденции и перспективы развития // Москва. Федеральное агентство по печати и массовым коммуникациям. 2018. 91 с.

6. Постатейный комментарий к Бернской конвенции об охране литературных и художественных произведений / Под редакцией И.А. Близнеца // Интеллектуальная собственность. Документы и комментарии. 2004. № 6. С. 2-92.

7. Право интеллектуальной собственности / Под ред. И.А. Близнеца. Москва. 2015. 896 с.

8. Ситдикова Р.И. Обеспечение частных, общественных и публичных интересов авторским правом. Москва. 2013. 159 c.

Поступила в редакц̧ию 07.11.2018 